\title{
IMPLEMENTASI SIOP BERBANTUAN MATHLET UNTUK MENINGKATKAN KUALITAS PEMBELAJARAN MATEMATIKA BILINGUAL
}

\author{
Gede Suweken \\ Jurusan Pendidikan Matematika, Fakultas Matematika dan IImu Pengetahuan \\ Alam, Universitas Pendidikan Ganesha, Singaraja Indonesia
}

e-mail: gdsuweken5@gmail.com

\begin{abstract}
Abstrak
Sebenarnya penyelenggaraan Rintisan Sekolah Bertaraf Internasional (RSBI) merupakan salah satu upaya pemerintah untuk meningkatkan kinerja sekolah untuk mewujudkan tujuan pendidikan nasional. Selain itu, sekolah-sekolah dengan predikat RSBI juga diharapkan mampu menjadi wadah bagi siswa-siswa berkualitas dalam mempersiapkan diri agar mampu bersaing di era global. Karena tuntutan yang tinggi tersebut, maka sekolah yang biasanya ditunjuk menjadi sekolah penyelenggara RSBI adalah sekolah dengan siswa-siswa yang unggul, terutama secara akademik Ditinjau dari tujuan mulia ini, maka seharusnyalah best practice yang sudah terlaksana selama ini di sekolah-sekolah mantan RSBI diteruskan baik dengan maupun tanpa predikat RSBI. Namun demikian, kenyataan menunjukkan bahwa kualitas pembelajaran matematika pada sekolah-sekolah tersebut masih jauh dari harapan. Penggunaan bahasa Inggris dalam pembelajaran juga masih sangat terbatas. Sehingga diperlukan suatu inovasi pembelajaran yang mampu memadukan kedua tuntutan ini, yaitu bagaimana kita menyelenggarakan pembelajaran yang tidak hanya mampu meningkatkan penguasaan bidang studi tetapi juga penguasaan bahasa. Salah satu upaya yang bisa ditempuh adalah dengan mengimplementasikan SIOP dalam pembelajaran. Mengingat keterbatasan baik guru maupun siswa dalam pelaksanaan SIOP ini, maka pembelajaran harus dibantu dengan pemanfaatan media sehingga bagi siswa yang terkendala memahami konsep secara verbal bisa memahaminya melalui eksplorasi visual pada mathlet.
\end{abstract}

Kata kunci: SIOP, mathlet, kualitas pembelajaran, inovasi.

\begin{abstract}
One goal of carrying out International Level Pionering School (RSBI) is to improve the school performance in order to achieve the national goals of education. Besides that International Level Pionering School is also expected to be able to provide qualified students to prepare theirshelve to be able to compette globaly. Because of the high expectation, schools that usualy aske to carry out this program are schools with bright students academically. From the view of this noble purposes, best practices that have been run so far should be continued regardless of whether or not schools are being RSBI or not. However, in fact mathematics learning quality in those ex RSBI schools are still far from expectation. Also the use of English during the learning process are still too limited. Therefore, learning
\end{abstract}


innovation which is able to blend qualified subject learning and qualified language acquisition is needed. One of these learning model is SIOP model. The SIOP is developed in order to make grade level academic content to be more acessible to students while at the same time promoting their English language development. However, due to the English limitation of students and teachers, the use of SIOP in mathematics learning should be accompanied by the help of mathlet, so that students who face difficulties in understanding mathematics concepts analytically will be able to understand them visualy through the exploration of the mathlet.

Keywords: SIOP, mathlet, learning quality, innovation.

\section{PENDAHULUAN}

Sebenarnya penyelenggaraan Rintisan Sekolah Bertaraf Internasional (RSBI) me-rupakan salah satu upaya pemerintah untuk meningkatkan kinerja sekolah untuk mewu-judkan tujuan pendidikan nasional. Selain itu, sekolahsekolah dengan predikat RSBI juga diharapkan mampu menjadi wadah bagi siswa-siswa berkualitas dalam mempersiapkan diri agar mampu bersaing di

Siswa-siswa pada sekolah-sekolah tadi, selain harus menguasai kompetensi standar nasional pendidikan (SNP), juga harus menguasai kemampuan-kemampuan kunci global tertentu, khususnya dalam bidang matematika, sains, teknologi infor-masi dan komunikasi dan bahasa asing. Pengakraban siswa pada nilai-nilai global yang diunggulkan selayaknya digunakan sebagai acuan dalam penyelenggaraan se-kolah yang berkualitas. Pengakraban siswa kepada nilai-nilai tersebut, pada saatnya nanti, diharapkan mampu mempersempit kesenjangan Indonesia dengan negaranegara maju, khususnya dalam bidang ekonomi, sain dan teknologi.

Namun demikian, matematika sebagai salah satu pelajaran pokok, pembelajarannya masih belum mengarah kepada penguasaan kemampuan global yang di-unggulkan tadi. Kualitas era global (Depdiknas, 2003). Karena tuntutan yang tinggi tersebut, maka sekolah yang ditunjuk menjadi sekolah penyelenggara RSBI adalah sekolah dengan siswa-siswa yang unggul, terutama secara akademik. Walaupun kini RSBI telah dihentikan, mengingat potensi akademik siswa yang unggul tersebut, sekolah-sekolah mantan RSBI tersebut pada umumnya akan melanjutkan program-program tersebut. pembelajaran matematika pada sekolah-sekolah unggul tadi tidak berbeda secara signifikan dengan kualitas pembelajaran matematika pada sekolah-sekolah reguler. Standar proses pembelajaran yang mengacu pada peng-uasaan kemampuan global yang unggul, seperti kemampuan pemecahan masalah, kemampuan penalaran, kemampuan komu-nikasi matematis, kemampuan mengaitkan konsep, dan kemampuan multi-representasi masih belum menjadi ciri dari pembelajaran matematika kita. Pembelajaran matematika sampai saat ini masih didominasi oleh pembelajaran yang sifatnya memorisasi dan recall, jauh dari pembelajaran yang membuat siswa bisa merasakan "the joy of discovery." Sebagai akibat dari kualitas pembelajaran yang rendah ini, secara umum siswa-siswa SMP masih belum mampu mengaitkan konsep-konsep 
dalam matematika, belum mampu melihat konsep secara multirepresentasi, dan belum memiliki kemampuan komunikasi dan pemecahan masalah yang baik. Kelemahan ini terlihat jelas setiap kali penulis membina siswa-siswa SMP dalam rangka seleksi siswa-siswa peserta OSN matematika.

Begitupun halnya dengan penggunaan bahasa Inggris sebagai pengantar pembelajaran masih belum terimple-mentasikan secara signifikan. Penggu-naannya masih sangat minim, terbatas greetings dan bagian awal pembelajaran lainnya, seperti penyampaian tujuan pem-belajaran, dan bagian akhir pelajaran seperti rangkuman dan menutup pelajaran. Bagian inti pelajaran yang sifatnya akade-mik, masih tetap didominasi oleh bahasa Indonesia. Untuk mengatasi kendala ini, beberapa guru memang sudah dikursuskan bahasa Inggris. Namun kursus yang mere-ka ikuti masih bersifat umum sehingga belum cukup memadai untuk digunakan sebagai bahasa pengantar dalam menga-jarkan bidang studi yang diampunya, khususnya matematika yang sifatnya abstrak. Upaya serius untuk meningkatkan kom-petensi Bahasa Inggris para guru yang terkait langsung dengan bidang studi yang diampunya (Cognitive Academic Language Profiency, CALP) harus dilakukan, sehing-ga menghasilkan lulusan dengan pengu-asaan materi dan bahasa seperti yang diharapkan.

\section{HASIL DAN PEMBAHASAN}

\section{Model Pembelajaran SIOP}

Salah satu upaya yang bisa dilakukan untuk mengatasi masalah di atas adalah dengan mengimplementasikan model pembelajaran Sheltered Instruction Observation Protocol (SIOP) dalam pem-belajaran matematika. SIOP dikembangkan sebagai suatu upaya untuk membantu siswa-siswa ELs (English Learners) agar mampu mencapai kompetensi bidang studi sambil mengembangkan kemampuan baha-sa Inggrisnya. SIOP sebenarnya terdiri dua komponen, yaitu sheltered instruction dan observation protocol. Menurut pengembangnya (Echevarria, et.al., 2008):"Sheltered Instruction is an approach for teaching content to English learners (Els) in strategic ways that make the subject matter concepts comprehensible while promoting the students' English development."

Sedangkan Observation Protocol adalah pedoman observasi yang digunakan untuk memantau proses pembelajaran agar senantiasa mengarah kepada proses pembelajaran yang berkualitas.

Sebagai suatu model pembelajaran, SIOP didisain untuk membantu guru agar mampu membelajarkan dua hal sekaligus, yaitu materi bidang studi dan kemampuan bahasa Inggris, secara sistematik, konsis-ten, dan concurrent.

\section{Komponen-komponen Sheltered Instruction dari SIOP}

SIOP terdiri dari dua komponen, yaitu Sheltered Instruction dan Observation Protocol. Melalui Sheltered Instruction guru diharapkan memanfaatkan berbagai teknik dan alat untuk membuat materi pelajaran mudah dipahami siswa yang saat itu juga sedang belajar bahasa Inggris. Sedangkan Observation Protocol adalah pedoman observasi yang 
digunakan untuk memonitor aktivitas mengajar guru agar selalu mengarah pada proses pembelajaran yang berkualitas.

Sebagai Sheltered Instruction, SIOP terdiri dari 8 komponen sebagai berikut:

\section{a. Persiapan (Preparation)}

Pentingnya perencanaan bagi suksesnya suatu proses pembelajaran tidak perlu dipertanyakan lagi. Agar pembelajaran yang optimal bisa terjadi, maka perencanaan harus mulai dengan memikirkan bagaimana mengaitkan pembelajaran yang akan dilaksanakan dengan pengalaman dan pengetahuan awal siswa. Perencanaan terdiri dari berbagai kegiatan, seperti (i) Merumuskan dan menuliskan tujuan bidang studi dan bahasa, (ii) Menyesuaikan konsep dengan latar belakang pengalaman dan pengetahuan siswa, (iii) Menyiapkan materi suplemen untuk memudahkan siswa memahami ma-teri pelajaran, (v) Menyiapkan aktivitas meaningful yang mengaitkan materi yang dipelajari dengan tujuan bahasa yang harus dicapai, dan (vi) Menyesuaikan isi buku yang dipakai dengan kemampuan siswa.

\section{b. Membangun latar (Building Background)}

Dalam SIOP, guru harus mengaitkan konsep baru dengan pengalaman dan pengetahuan awal siswa. Pembelajaran yang efektif akan mengantarkan siswa dari statusnya saat ini ke tingkat yang

lebih tinggi (Krashen, 1985). Siswa pebelajar bahasa Inggris harus diberikan kesempatan untuk menggunakan, mende-ngar, membaca, menulis, dan mengucap-kan bahasa
Inggris dalam konteks materi bidang studi. Beberapa kegiatan yang termasuk bagian ini adalah: (i) Mengkaitkan secara eksplisit konsep yang dipelajari dengan latar belakang pengalaman siswa, (ii) Mengkaitkan secara eksplisit konsep yang dipelajari dengan pengetahuan awal siswa, dan (iii) Memberikan penekanan pada kata-kata kunci yang digunakan de-ngan cara memperkenalkan, menuliskan, menggunakannya berulang-ulang, dan menonjolkannya agar dapat dilihat siswa.

\section{c. Input yang komprehensif (Comprehensible Input)}

Guru SIOP yang efektif harus mempertimbangkan siswa yang sedang belajar bahasa Inggris. Untuk siswasiswa ini, guru harus membuat komunikasi verbal bisa dipahami siswa dengan cara meng-ako-modasi kebutuhan bahasa siswa tersebut. Bagimana mencapai hal ini? SIOP meng-anjurkan hal-hal berikut: (i) Pengucapan harus disesuaikan dengan kemampuan siswa, (ii) Uraian tentang tugas_tugas akademik harus jelas, dan (iii) Penggunaan teknik yang bervariasi untuk membuat konsep mudah dipahami.

\section{d. Strategi pembelajaran (Strategies)}

Guru yang baik harus mampu membuat siswa bisa mengases informasi yang sudah dimiliki, mampu membuat siswa bisa mengaitkan pengetahuan awal mereka dengan pengetahuan yang sedang dipe-lajari, mampu membuat siswa memecahkan masalah, dan menyerap materi baru yang dibelajarkan. Agar siswa bisa mencapai semua ini, maka (i) Guru harus 
memberikan kesempatan kepada siswa untuk menggunakan berbagai strategi belajar; metakognitif, kognitif, dan sosial (afektif), (ii) Guru harus bisa melakukan berbagai teknik scaffolding dalam pem-belajaran, dan (iii) Guru harus mampu membangkitkan higherorder thinking mela-lui berbagai tugas atau pertanyaan.

\section{e. Interaksi (interaction)}

Praktek sangat diperlukan untuk memfasihkan siswa dalam berbahasa Ing-gris. Untuk itu, guru harus (i) Memberikan kesempatan kepada siswa untuk berin-teraksi dengan menggunakan bahasa Ing-gris, (ii) Memanfaatkan pembelajaran ko-operatif untuk mendukung siswa mengembangkan bahasa dan bidang studi yang dipelajari, (iii) Memberikan waktu yang cukup agar siswa mampu memberikan respon dengan baik, dan (iv) Memberikan siswa kesempatan untuk menjelaskan konsep bidang studi yang dipelajari dalam bahasa ibu mereka.

\section{f. Praktek dan Aplikasi (Practice and Aplication)}

SIOP menyarankan guru untuk selalu mencek pemahaman siswa dengan cara memberikan kesempatan kepada siswa untuk mempraktekkan materi yang telah dipelajari. Selain itu, guru juga harus memberikan kesempatan kepada siswa untuk mengaplikasikan konsep yang sudah dipelajari ke situasi baru. It is well established that practice helps one master a skill (Jensen, 2005). Dalam SIOP, praktek dan aplikasi harus melibatkan ke empat keterampilan bahasa, yaitu membaca, men- dengarkan, mengucapkan, dan menuliskan. Untuk mencapai hal ini, (i) Gunakan alat peraga untuk membantu siswa dalam memahami materi bidang studi, (ii) Berikan siswa kegiatan untuk mengaplikasikan materi yang terkait dengan bidang studi dan bahasa, dan (iii) Berikan siswa kegiatan yang mengintegrasikan ke empat keterampilan bahasa.

\section{g. Pelaksanaan (Lesson Delivery)}

Seperti yang sudah diuraikan sebelumnya, perencanaan yang baik adalah lang-kah pertama bagi terselenggaranya pembelajaran yang baik. Namun, pembe-lajaran bisa menjadi berantakan, walaupun sudah direncanakan dengan baik. Aktifitas yang terlalu mudah atau terlalu susah, pembelajaran yang terlalu singkat atau terlalu panjang, diskusi berkepanjangan (walaupun menarik namun tidak terkait dengan materi yang dibahas), adalah beberapa kejadian yang bisa membuat proses pembelajaran berantakan. SIOP menyarankan beberapa langkah agar guru senantiasa pada jalur yang tepat, yaitu (i) Tuliskan tujuan bidang studi yang ingin dicapai sehingga siswa dan guru senan-tiasa berusaha untuk mencapainya, (ii) Tuliskan tujuan bahasa yang ingin dicapai sehingga siswa dan guru senantiasa berusaha untuk mencapainya, (iii) Libatkan siswa. Siswa harus terlibat $90 \%-100 \%$ dalam pembelajaran. Terutama, keter-libatan siswa dalam pembelajaran yang kurang dari $50 \%$ adalah hal yang idak bisa diterima, dan (iv) Sesuaikan kecepatan pembelajaran dengan kemapuan siswa. 


\section{h. Review dan asesmen (Review and Assessment)}

Selain perencanaan, semua komponen SIOP sebenarnya tidak bersifat hirarkis. Interaksi yang baik, misalnya, tentu harus muncul sepanjang pembelajaran agar siswa bisa mencapai tujuan pembelajaran. Demikian juga halnya dengan Compre-hensible Input, selalu harus diusahakan guru agar materi bisa dipahami siswa dengan baik. Jadi, peletakan Review dan asesmen pada langkah ke delapan, bukan berarti komponen ini adalah bagian terkahir dalam model SIOP. Asesmen dan pembelajaran adalah dua hal yang tidak bisa dipisahkan. Guru yang efektif akan meng-gunakan hasil-hasil yang diperoleh melalui asesmen untuk membuat perencanan beri-kutnya agar pembelajaran menjadi sesuai dengan kebutuhan dan kekuatan siswa. Guru yang efektif juga menyadari penting-nya asesmen yang kontinyu baik untuk mencek ketercapaian tujuan bidang studi maupun tujuan bahasa. Karena itu (i) Review secara menyeluruh perbenda-haraan kata yang penting, (ii) Review se-cara menyeluruh konsepkonsep bidang studi yang penting, (iii) Balikan segera dan teratur terhadap respon siswa harus diberikan, dan (iv) Lakukan asesmen ter-hadap pemahaman siswa terhadap semua tujuan pembelajaran, baik yang menyang-kut tujuan bidang studi maupun tujuan bahasa.

\section{Komponen-komponen Observation Protocol dari SIOP}

Seperti telah dinyatakan sebelumnya, SIOP bisa dipakai baik sebagai pen-dekatan pembelajaran maupun sebagai alat observasi apakah guru telah menye-lenggarakan pembelajaran mereka sesuai kaidah-kaidah pembelajaran yang baik bagi siswasiswa sheltered. Dalam kaitannya dengan fungsi kedua ini, SIOP dikenal sebagai SIOP Protocol. SIOP protocol berisi item-item yang sama dengan fiturfitur dari komponen model pembelajaran SIOP. Ini tentu tidak terlalu mengejutkan, karena seorang guru haruslah diobservasi pada perilakuperilaku yang diharapkan untuk dilaksanakan. SIOP protocol tidak dimak-sudkan untuk menilai guru, melainkan untuk mengobservasi apakah perilaku guru yang mendukung pembelajaran untuk siswa-siswa sheltered telah muncul dalam pembelajaran atau belum. Hasil observasi ini kemudian didiskusikan dengan guru yang bersangkutan untuk kepentingan perbaikan bagi pembelajaran berikutnya. Jika bebe-rapa guru dilibatkan pada implementasi SIOP ini, maka lesson study memperoleh tempatnya yang sangat real dan berman-faat pada praktek-praktek pembelajaran kita.

\section{Peranan TIK dalam SIOP}

Seperti yang telah diketahui, bahwa belajar matematika berkenaan dengan ide-ide abstrak (konsep), struktur-struktur, serta hubunganhubungannya yang diatur dalam urutan logis. Karena 'mahluk-mahluk' matematika adalah 'mahluk-mahluk' yang abstrak, maka siswa harus terlibat secara aktif agar ia bisa mengenali mahluk tersebut untuk pada akhirnya mengkonstruksi kem-bali pola, struktur dan hubungan-hubungan yang ada diantara konsep-konsep abstrak tersebut. "Knowledge must be 
constructed by the learner; it can not be supplied by the teacher. We are all responsible for our own learning; no one can learn for us" (Sigfried M. Holzer dan Raul H. Andruet, 2000). Apalagi siswa SMP yang masih berada pada tahap peralihan dari tahap operasi konkrit ke tahap operasi formal maka kesempatan bermain-main dengan konsep yang abstrak tersebut harus diberikan. Bahkan Ausubel (dalam Herman Hudoyo, 2003) menekankan bahwa seorang maha-siswa pun (sudah berada pada tahap operasi formal) bila dihadapkan pada suatu suatu konsep yang benar-benar baru, pertama-tama ia akan mendekatinya secara konkrit. Karena itu, pembelajaran mate-matika hendaknya: (1) memberikan kesempatan kepada siswa untuk menemukan pola-pola atau hubungan, (2) memberikan kesempatan kepada siswa untuk melakukan percobaan, (3) mendorong siswa untuk menemukan adanya urutan, perbedaan, perbandingan, pengelompokan, dan sebagainya, (4) mendorong siswa untuk menarik kesimpulan umum, dan (5) membantu siswa memahami dan menemukan hubungan antara konsep satu dengan lainnya. (Depdiknas, 2004).

Yang menjadi masalah sekarang adalah, bagaimanakah caranya agar siswa mendapat kesempatan bereksperimen dan mengeksplorasi Eksperimen dan eksplorasi konsep ini bisa dilakukan secara numerik maupun visual dalam bentuk grafik atau animasi. Semua interaksi ini terjadi secara 'live' di layar monitor, sehingga siswa tidak perlu me-nunggu lama untuk mengetahui apakah respon yang diberikannya benar atau salah. Perolehan balikan yang segera juga konsep? Untuk materi-materi yang sangat mendasar, penjumlahan dan pengurangan, misalnya, siswa bisa menggunakan benda-benda konkrit. Tetapi untuk materi-materi yang sudah agak lanjut, penggunaan benda-benda konkrit kadang-kala tidak mungkin. Konsep tentang gradien (kemiringan) garis lurus, posisi dua garis pada bidang datar (kesejajaran, ketegak-lurusan, keterpotongan), peranan $\mathrm{a}, \mathrm{b}$ dan $\mathrm{c}$ dalam fungsi kuadrat $y=a x^{2}+b x+c$, adalah beberapa contoh konsep matematika yang tidak mungkin dicarikan benda konkritnya. Dalam hal inilah komputer bisa sangat membantu (Suweken, 2011). Menurut penulis, inilah esensi dari peman-faatan TIK dalam pembelajaran matema-tika. Dengan program-program sederhana yang terfokus pada suatu konsep (mathlet), siswa akan bisa dibantu untuk "merasakan" atau "memaknai" suatu konsep yang dipe-lajari sebelum konsep tersebut diabstraksi. "By helping people visualize and exp-eriment with mathematical phenomena, modern computing technology have changed the way all people learn and work. In school they can influence how mathemtics is learnt and taught." (Albert. A Cuoco, et.al, 1995). Jadi, dengan bantuan mathlet siswa dimungkinkan untuk melakukan eksperimen, eksplorasi terhadap konsep-konsep yang sedang dipelajari. akan merupakan motivasi yang kuat bagi siswa untuk belajar. Jadi, dengan bantuan mathlet konsep-konsep matematika akan bisa dikonstruksi siswa kembali melalui eks-plorasi dan eksperimentasi. Melalui proses ini, pemaknaan konsep akan berjalan dengan baik sehingga pemahaman 
siswa bisa diharapkan akan menjadi lebih baik.

Dalam kaitannya dengan SIOP, peranan TIK (khususnya mathlet), bagi terselenggaranya pembelajaran yang baik adalah jelas. Mengingat kemampuan baha-sa Inggris siswa yang masih sangat terbatas, maka tentu saja mereka akan mengalami kendala dalam memahami materi yang disampaikan secara verbal dalam bahasa Inggris. Dalam hal inilah mathlet akan sangat bermanfaat dalam meningkatkan pemahaman siswa, melalui rekonstruksi kembali konsep-konsep yang belum dipahami tersebut, bukan secara verbal, melainkan secara eksploratif melalui visualisasi dan eksperimentasi.

\section{Kendala yang dihadapi}

Walaupun SIOP telah digunakan secara luas dan berhasil di berbagai belahan dunia, implementasinya di Indonesia masih memerlukan pengkajian lebih jauh. Kendala utama dari implementasi SIOP berbantuan mathlet adalah guru. Kemampuan bahasa Inggris guru matematika masih sangat ter-batas, di samping kemampuannya mem-buat dan mengintegrasikan mathlet dalam pembelajaran matematika. Secara lebih spesifik, beberapa hal berikut memerlukan pengkajian lebih mendalam:

1) Kata-kata (vocabulary) dan struktur-struktur bahasa Inggris (grammar) apakah yang relevan untuk mate-matika siswa SMP kelas VIII,

2) Konsep-konsep matematika yang perlu dibuatkan mathletnya,
3) Kendala-kendala yang dialami guru dalam merancang dan membuat mathlet,

4) Kendala-kendala yang dialami guru dalam mengembangkan perangkat pembelajaran (RPP dan LKS) berorientasi SIOP dan berbantuan mathlet, dan

5) Pada tahun II, penelitian diarahkan untuk mengetahui apakah model SIOP memang berpengaruh positif terhadap hasil belajar matematika siswa, khususnya siswa SMP kelas VIII, serta

6) Kendala-kendala yang dialami guru dalam pembelajaran menyelenggarakan berorientasi SIOP.

Penelitian Unggulan Perguruan Tinggi (PUPT) yang diusulkan untuk 2 tahun ini dimaksudkan untuk mengkaji masalah-masalah di atas. Tujuan akhir penelitian tentu saja untuk meningkatkan kualitas proses pembelajaran matematika dengan penekanan lima standar proses pembelajaran, yaitu: pemecahan masalah, penalaran, komunikasi matematis, keterkaitan antar konsep, dan multiple-representasi. Proses pembelajaran di atas akan diselenggarakan secara bilingual dengan bantuan mathlet agar lebih mudah dipahami siswa.

\section{Hasil Tahun I}

Pada tahun I, penelitian diarahkan untuk mengkaji 4 masalah pertama di atas. Pada tahun I ini peneliti dan guru telah berhasil mengidentifikasi kata-kata dan mengembangkan struktur-struktur bahasa terkait dengan matematika kelas VIII seperti berikut: 
1) "This shape is a circle because...."

2) "This part/component of a circle is called...."

3) "To determine the value of $\pi, I$ do the following: 1 ...., $2 \ldots ., 3 \ldots .$.

4) "The circumference of a circle is determined by using the formula ..., and the result is...."

5) "The area of a circle is determined by using the formula...., and the result is..."

6) "By exploration, it seems that the measure of a circumference angle is twice the measure of a center angle"

7) "Since the angle measure of a straight line is $180^{\circ}$, then the measure of a circumference angle facing a diameter is...."

8) "The area of this sector is determined by ...."

9) "An inner circle of a circle can be constructed by...."

10) "An outer circle of a circle can be constructed by...."

11) "An angle measure between a tangent and a radius is...."

12) "From a point outside a circle, we can draw only two tangents to a circle."

13) "Two circles will intersect if..."

14) "Two circles will tangent if..."

15) "Two circles will independent to each other if...
16) "The length of outer common tangent is determined by: (1)...., (2)...., (3)...."

17) "The length of inner common tangent is determined by: (1)...., (2) ...., (3)...."

18) "The cube is consisted of 6 sides, 8 vertices, and ...."

19) "There are ... side diagonals, and ... space diagonals"

20) "There are ... distinct numbers of nets of a cube"

21) "The volume of a prism can be computed by using..."

22) "The total area of sides of a cuboid is..."

23) "Since there are 5 sides of a triangular prism, then..."

Seperti yang telah dinyatakan sebelumnya, kemampuan bahasa Inggris guru dalam hal ini memang masih sangat ter-batas. Namun demikian, dengan tujuan yang jelas, yakni bahasa Inggris yang berkaitan dengan pembelajaran matema-tika, tampaknya kendala bahasa ini tidak akan sulit diatasi.

Berkaitan dengan mathlet, guru dan peneliti telah membuat beberapa mathlet untuk pembelajaran matematika SMP kelas VIII. Pertama-tama ditampilkan contoh-contoh mathlet berkaitan dengan bidang datar, kemudian diikuti dengan contoh-contoh mathlet berkaitan dengan bangun ruang. 


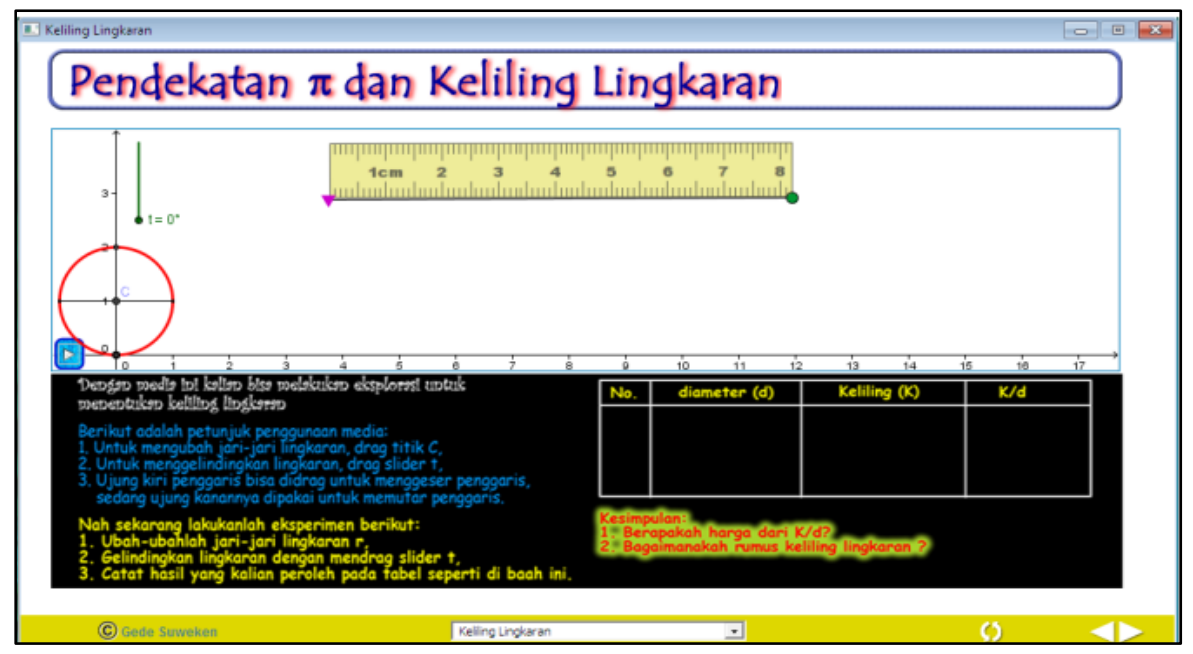

W. Luas Lingkaran

\section{Luąs Lingkarạn}

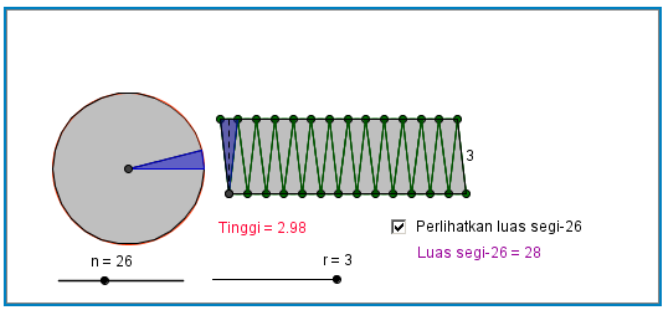

Dengan media ini kalian akan belajar tentang bagaimana menurunkan umus luas lingkaran.

Kalian bisa bereksperimen dengan cara mendrag slider yang disediakan.

Drag r untuk mengubah jari-jari lingkaran, dan drag $\mathrm{n}$ untuk mengubah segibanyaknya.
Tatapkan jari-jari lingkaran $=2$, dan segibanyak $=$ segi-10 Apa yang kalian lihat? Apakah luas lingkaran = luas segi-

10 ?

Bisakah kamu menentukan berapa luas segi-10? Jadi.

Sekarang, perbesar seginya meniadi segi-16. Apa yang kamu lihat? Apakah segi-16 sudah mendekati lingkaran? Berapakah luas segi-16?

Perbesar segibanyak menjadi segi-30, apa yang kamu lihat? Berapakah luas segi-30? Kira-kira berapakah luas lingkarannya?

Bayangkan sekarang segibanyaknya terus diperbesa Tentu saja segibanyak ini akan semakin mirip dengan lingkaran.

政 tinggi jajargenjang terse but?

Jadi berapakah luas lingkarannya?

Gunakan rumus yang kamu peroleh untuk menghitung luas lingkaran dengan $r=3$. Apakah prediksimu sesai dengan luas segi-30? 


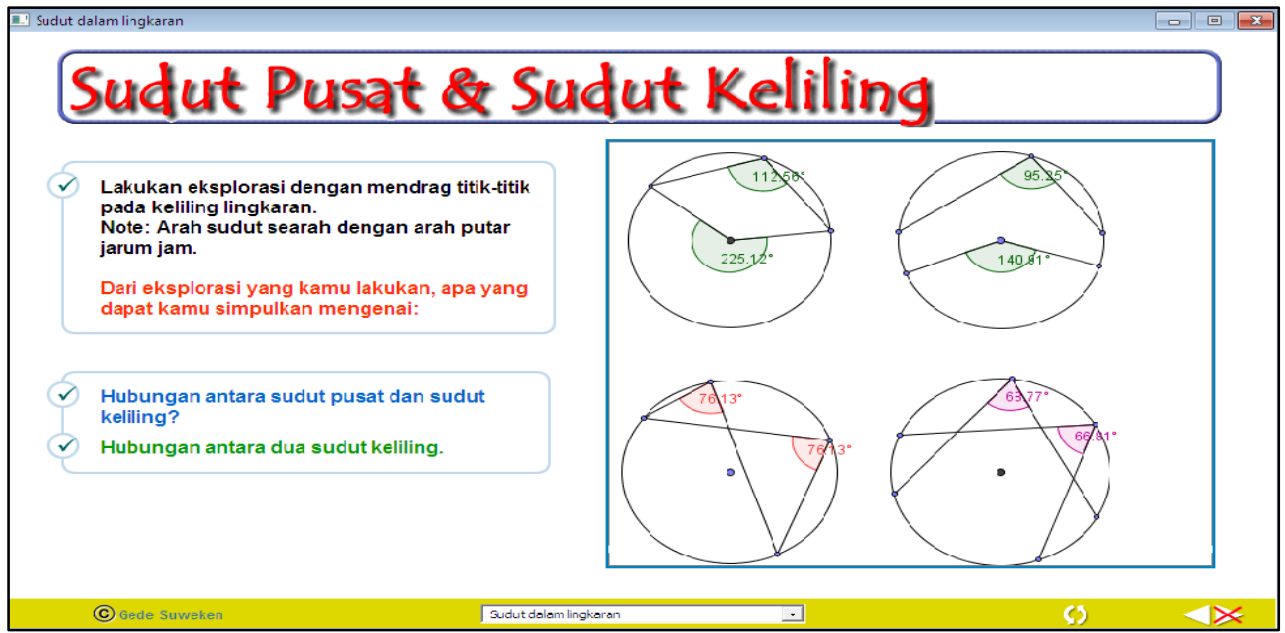

Gambar 1: Beberapa mathlet matematika Kelas VIIII berkaitan dengan bidang datar

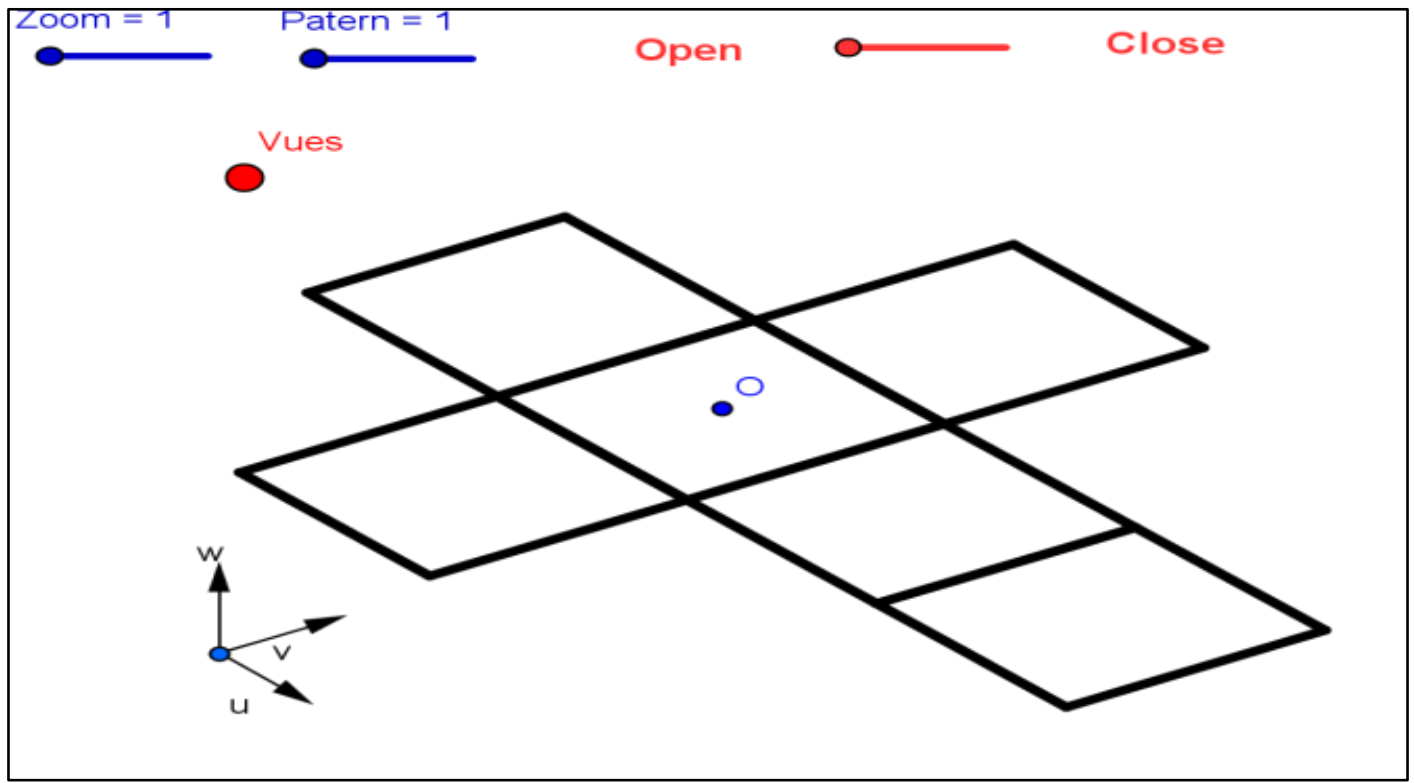




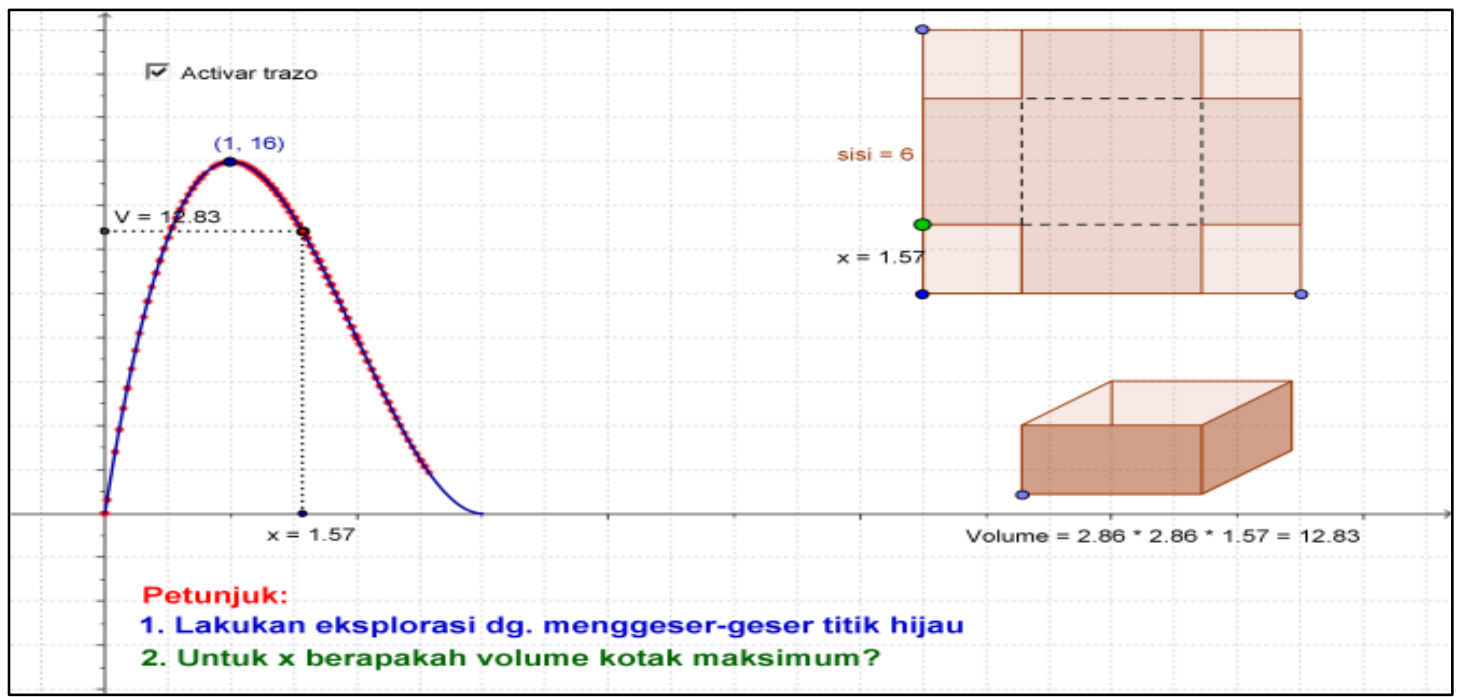

Gambar 2: Beberapa mathlet tika matem SMP kelas VIII berkaitan dengan bangun ruang.

Selain pola bahasa dan mathlet-mathlet di atas, rencana pelaksanaan pembelajaran (RPP) dan Lembar Kerja Siswa juga telah dibuat bersama-sama guru tanpa kendala yang berarti kecuali kendala dari segi baha-sa. Karena perangkat-perangkat tersebut dibuat bersama-sama guru, maka kesesuaiannya dengan kurikulum dan kondisi siswa tentu sudah memenuhi syara. Namun demikian, apakah implementasi dari model SIOP beserta semua perangkat yang sudah disusun di atas akan menimbulkan efek positif, masih menunggu penelitian tahun berikutnya.

\section{PENUTUP}

Model SIOP berbantuan mathlet secara potensial akan dapat meingkatkan kualitas pembelajaran matematika bilingual, baik ditinjau dari sudut siswa maupun dari sudut pengembangan keprofesionalan guru.
Hal ini disebabkan karena SIOP memberikan langkah-langkah yang harus ditempuh agar pembelajaran menjadi berkualitas dari su-dut penguasaan materi bidang studi dan dari sudut pengembangan kemampuan bahasa. Disamping itu SIOP juga memberikan petunjuk tentang bagaimana memonitor proses pembelajaran agar senantiasa berjalan kearah yang lebih baik.

Mengingat penelitian ini masih bera-da pada tahap pertama yang isinya masih bersifat persiapan untuk penelitian yang sesungguhnya, maka masih belum ada hal-hal yang bisa disarankan terkait dengan hasil penerapan SIOP dalam pembelajaran matematika. Namun, pengalaman bekerja sama dengan guru dalam rangka persiapan perangkat untuk penelitian pada tahun II, memberikan refleksi kepada peneliti dan guru bahwa: 
1) Cara terbaik untuk menyampaikan konsep matematika harus terusmenerus disesuaikan dengan kondisi siswa,

2) Guru harus lebih banyak membaca tentang pembaharuan pembelajaran matematika, tentang problem solving, tentang soal-soal menarik,

3) Guru harus lebih banyak belajar bagaimana membuat mathlet yang menarik,

4) Guru harus lebih banyak mengintegrasikan Bahasa Inggris dalam pembelajaran matematika.

\section{DAFTAR PUSTAKA}

Cuoco, Albert A., E. Paul Goldenberg, and Jane Mark. 1995. Technology Tips. Constructions and investigations with dynamic geometry software. Technology in Perspective. No. 87. pp. $450-452$

Depdiknas. 2003. Undang-Undang Republik Indonesia Nomor 20 Tahun 2003 Tentang Sistem Pendidikan Nasional. Jakarta: Sekretariat Negara Republik Indonesia.

Depdiknas. 2004. Kurikulum 2004 Sekolah Menengah Pertama (SMP). Pedoman Khusus Pengembangan Silabus Berbasis Kompetensi SMP Mata Pela-jaran Matematika Jakarta: Direktorat Jenderal Pendidikan Dasar dan Menengah.

Depdiknas. 2007. Peraturan Menteri Pendidikan Nasional Republik Indonesia No. 41 Tahun 2007 Tentang Standar Proses Untuk Satuan Pendidikan Dasar dan Menengah.Jakarta: Departemen Pendidikan Nasional.
Echevarria, Jana, et.al. 2008. Making Content Comprehensible for English Learners. The SIOP Model. Singapore: Pearson Education, Inc.

Echevarria, Jana, et.al. 2010. The SIOP Model for Teaching Mathematics to English Learners. Singapore: Pearson Education, Inc.

Jensen, E. 2005. Teaching with The Brain in Mind. $2^{\text {nd }}$ Edition. Alexandria, VA: Association for Supervision and Curriculum Development.

Kompas.com 6/3/2012. 2012. Kemdikbud Harus Evaluasi RSBI. www.Kompas.com. Diakses tanggal 15 Maret 2012.

Krashen. 1985. There Roles for Reading for Minority-Language Children. In G.

Garcia (Ed.), 2003, English Learners; Reaching The Highest Level of Literacy Learning. Newark, DE: International Reading Association.

Moschkovich, Judith. 2005. Bilingual Mathematics Learners: How Views of Language, Bilingual Learners, and Mathematical Communication Impact Instruction. Online. Diakses tanggal 15 Maret 2012.

National Council of Teachers of Mathematics (NCTM). 2000. Priciples and Standards for School Mathematics. Reston, VA: NCTM.

Short, D. 1994. Expanding Middle School Horizons: Integrating language, culture, and Social Studies. Tesol Quarterly, 28(3), 581-608. Holzer, Sigfried M. and Raul H. Andruet. 2000. Active Learning. Online. Diakses tanggal

Jurnal Pendidikan Indonesia |583 
20 Januari 2015. Suweken, Gede 2011. Pengembangan Mathlet Matematika Eksploratif Untuk Meningkatkan Kompetensi Matematika Siswa SMP Kelas VIII di Singaraja. Laporan Pelitian
Hibah Bersaing. Singaraja: Lembaga Penelitian Undiksha.

Wuradji dan Muhyadi. 2011. Implementasi Program Rintisan Sekolah Bertaraf Internasional (RSBI) di Kota Yogya-karta. Laporan Penelitian. Yogyakarta: UNY. 